\title{
Bridges for the Domestic Technology Gap
}

by our Washington Correspondent

Plans now being devised in Washington for bringing science and technology to bear on problems such as pollution control, health care and urban renewal have an important factor in common-they deal with issues traditionally the concern of state and local governments. But there are increasing complaints from outside Washington that state and local groups have little or no influence on federal science policy, and that the machinery for transferring technology from federal agencies to the states and localities is inadequate (see Nature, 237, 479; 1972). Last week, these complaints were finally formulated as a series of explicit resolutions drafted by a committee appointed at a conference on this subject in the summer.

The resolutions are printed in an elegant and glossy document whose title, Action Now*, sums up the message. They are directed at three chief goalsthe establishment of state and local representation in the corridors of power in Washington, the strengthening of science policy at state and local levels and the forging of new links between the three levels of government, industry and the universities. Many of the proposals are not new, but most of them could be carried out without much delay and without a great amount of upheaval.

The most persistent theme that ran through the conference and which crops up in the resolutions is the desire for a state and local voice in federal policy making. One recommendation is that there should be established by the White House an Intergovernmental Council for Applied Science and Technology representing federal, state and local governments as well as industrial and academic scientists. Similar representation, the committee suggests, should be included on the policy and advisory bodies of the chief federal agencies concerned with science and technology, on the President's Science Advisory Committee and on the National Science Board. Moreover, to ensure that adequate links are forged between the three layers of government, a senior official should be designated in each federal agency to oversee intergovernmental science and technology.

The idea behind these suggestions is that since most of the new directions of policy in science and technology involve problems such as pollution, where regional disparities are great and which

*Available from Pennsylvania Office of Science and South Office Building, Harrisburg, Pa 17120. require action at state and local level, there should be adequate input at the planning stage from those whose job it is to make the policies work. But there is also a strong feeling running through the resolutions that the vast expenditures by the federal government on defence and space research during the past two decades could also bear fruit in applications at the state and local level. Representation on the planning and advisory bodies in Washington may help to transfer some of this technology to the states and localities, but the committee has other ideas for oiling the cogs of the technology transfer machinery.

Thus the committee suggests that federal laboratories should provide consultative and project management assistance to states and localities in applying science and technology to public services. The money for such linkages should come from the National Science Foundation or the Department of Commerce, possibly from the New Technology Incentives Programme now being run by NSF and the National Bureau of Standards. Another idea is that the federal government should provide some money for demonstration programmes for applied research on problems of state and local concern. The suggestion is that such money would be allocated by a board made up of members of state and local government, industry and the universities, and the committee believes that five states should initially take part.

Although, by implication, the com. mittee accuses the federal government of neglecting the task of transferring technology to state and local level, it does not suggest that Washington politicians and bureaucrats are entirely unaware of the problem. Indeed, President Nixon explicitly mentioned the need for forging new links between the three layers of government in his message to Congress on Science and Technology in March, Senator Edward M. Kennedy's National Science Policy and Priorities Act addresses many of the problems involved at the state and local level and the Office of Science and Technology and the National Science Foundation are also trying to bridge the gap. In fact, the domestic technology gap is at least partly the fault of the state and local governments themselves-many state administrations and nearly all state legislatures lack effective science policy advisory machinery, and they are only now becoming aware of their key role in the national science policy network.

Consequently, the committee asks for federal assistance in the establishment of full-time advisers and advisory groups to state governors as well as technical and analytical staff assistance to legislators. And the committee would also like to see 5,000 additional scientists and engineers in state and local government agencies within three years as well as a regular interchange of scientific personnel between levels of government, industry and the universities.

\section{HUMAN EXPERIMENTATION \\ Kennedy Tries Again}

by our Washington Correspondent

SENATOR EDWARD M. KenNedy is continuing his attempt to establish federal guidelines for experiments involving human subjects. In August, when the Military Procurement Authorizations Bill came up for debate in the Senate, he attached an amendment which would have prevented federal funds from being used for experiments on human subjects unless they were fully informed of the possible physical and

\section{Over the Hurdles}

by our Washington Correspondent

Congress has tied up the few remaining loose ends in the legislation designed to establish an Office of Technology Assessment and has sent the measure to President Nixon for his signature. Although President Nixon has been vetoing all sorts of legislation recently, it is unlikely that he will tread on Congress's toes by refusing to approve a bill that relates only to the legislative branch of the federal government.

Final action on the measure came last week when the House of Representatives agreed to the report of the conference committee set up to iron out the differences between the versions of the bill passed by the House of Representatives and by the Senate. The committee simply dotted a few i's and crossed a few t's in the Senate bill (see Nature, 239, 186; 1972), and its report was accepted without dissent. The office will probably begin its work of contracting out studies of the implications of legislation dealing with technological matters early next year. In the meantime, a suitable director must be found, and that will be no easy task. 